\title{
Judiciary's Hands are Tied by Fundamental Principles of State Policy for Protecting Human Rights: An Analysis of Bangladesh Constitution
}

\author{
Md. Rafiqul Islam Hossaini ${ }^{1}$, Md. Sazzad Hossain ${ }^{2}$ \\ ${ }^{I}$ Guest Lecturer, Department of Law, CCN University of Science and Technology, Bangladesh \\ ${ }^{2}$ Independent Researcher, LLM (LSBU, UK), LLB (Hon's) (UoL, UK)
}

\begin{abstract}
Constitution of the People's Republic of Bangladesh is the supreme law of the country that manifests the rules and regulations, by which the State and its citizen shall be governed. Apart from Part III of the Constitution of Bangladesh, some other human rights principles can also be found in Part II, as fundamental principles of state policy. Judicial hands are open in protecting those fundamental rights that are ensured under Part III of the Constitution of Bangladesh. However, this rule is not applicable for the principles laid down in Part II of the Constitution. Judicial hands are tied in respect of implementing those Fundamental Principles of State Policy. The government should also bear in mind that, those principles are the political commitments to the people at large, and should not be kept unimplemented for a long period of time. None knows when the government will achieve the goal of complete implementation of the fundamental principles, as there are still some unavoidable problems present in the State. However, if the judiciary's hands remains tied in protecting human rights, government might not be willing to ensure the fundamental rights, which might go against their own interests, and the goal to achieve access to justice and uphold rule of law will be remain as dream.
\end{abstract}

Keywords -Fundamental Principles of State Policy, Role of Judiciary, Human Rights, Bangladesh Constitution

\section{INTRODUCTION}

Protection of human rights is one of the most concerning issues across the world and Bangladesh is not an exception to this. Constitution of the People's Republic of Bangladesh is known as the supreme law of the country. The Constitution manifests the rules and regulations by which the State and its citizen shall be governed. Part II (Articles 8-25) of the Constitution of the People's Republic of Bangladesh broadly discusses the Fundamental Principles of State Policy. Protection of human rights is one of the core concepts in the Constitution of Bangladesh. Human rights are the rights that "derive from the inherent dignity of the human person". The crucial ideas that need to be explicated at the level of conceptions are rights, persons, and (inherent) human dignity; once this is done, it is relatively easy, even if still controversial, to develop a list. Apart from Part III of the Constitution of Bangladesh, some human rights principles can also be found in Part II as fundamental principles of state policy. All over the world, the judiciary is the most trusted organ for the people, where they can claim for the protection of their human rights apart from seeking remedies for the violation of those rights. For protecting human rights, the judiciary is undoubtedly playing the most authoritative role.

\section{BANGLADESH CONSTITUTION AND FUNDAMENTAL PRINCIPLES}

\section{OF STATE POLICY}

In the original Constitution of 1972 there were 4 basic principles, they were- Nationalism, Secularism, Socialism and Democracy. However, another principle namely "Absolute trust and faith in the Almighty Allah shall be the basis of all actions" has later replaced the principle of Secularism. The principle of Secularism has been reincorporated by the $15^{\text {th }}$ Amendment of the Constitution. Article 8 (1) of Part II of the Constitution provides that the principles of nationalism, socialism, democracy and secularism, shall constitute the fundamental principles of state policy. For making laws and for the interpretation of the Constitution and other laws of Bangladesh these principles shall play a controlling role. Moreover, Article 9 provides that, the unity and solidarity of the Bangalee nation is the basis of Bangalee nationalism, which has been attained through sharing common language and culture and attaining independence and sovereignty of Bangladesh through a determined struggling war of independence. 


\section{FUNDAMENTAL PRINCIPLES OF STATE POLICY AND HUMAN RIGHTS}

The principles of Socialism and freedom from exploitation have been discussed in Article 10 of the Constitution. This Article provides that, in terms of economic system, socialism shall be established to ensure justice and equality of all people, where there will be no exploitation of man by another man. To ensure justice, equality and human rights for all people and to stop exploitation of man by man, socialism is a fundamental principle of sate policy, which ensures an economic system based on state ownership of capital. By the proper implementation of this fundamental principle, justice and equality as well as un-exploitation of man can be assured, thus the constitutional protection of the human rights can also be achieved. But the State has not yet achieved this goal through the proper implementation of this principle. Vast work has to be done for the complete implementation of this principle.

The principle of Equality of opportunity, as a fundamental principle of state policy, has been ensured in Article19 of the Constitution. It is ensured that, it is the responsibility of the State to ensure equal opportunity for all of its citizens. The principle of equality is one of the basic principles of the human rights regime; and without ensuring the equality it is not possible to upheld rule of law and human rights in the society. It is the duty of the State to take all necessary initiatives for removing social and economic inequality among its citizens. It is the duty of the State to ensure equitable distribution of wealth and opportunities to acquire uniform level of economic development of the Republic. In addition to that, it is the responsibility of the State to ensure equal opportunity and participation of female citizens of the State in all spheres of national life. In most of the sectors of the State the equal opportunity for male and female citizens has been ensured but the expected level has yet not been achieved. However, in the recent philosophical literature on equality and modern practice of Bangladesh, a mystifying connection can be found as the modern human rights movement, is one of the most powerful manifestations of the commitment to equality. The new philosophical theory of egalitarianism has proceeded as, if there were no human rights movement or as if the idea of human rights was not an important expression of the commitment to equality. Thus the minimalist egalitarianism of human rights and the more strong egalitarianism of contemporary philosophical views of equality can be reconciled. But the concerning issue of this concept is the failure to concern about global inequalities and abandon the assumption, that one can develop an adequate theory of equality for the national case without theorizing about global justice.

A significant principle of Emancipation of peasants and workers is considered in Article 14 of the Constitution of the Peoples Republic of Bangladesh. This Article of the Constitution affirms this principle as a fundamental responsibility of the state to emancipate the toiling masses, the peasants and workers and backward sections of the people from all forms of exploitation. This Article of the Constitution governs as a safeguard principle for the toiling masses, the peasants and workers and backward sections of the society. As per this Article, it is a responsibility of the State to emancipate all sort of exploitation of peasants, workers and backward sections of the people. This fundamental principle has also not been completely implemented as there is still exploitation of the workers and drawback section of the society, and the imprecation of child labour. The State is still striving for the implementation of this principle through different laws and mechanisms.

Article 20 of the Constitution, however, deals with the fundamental principle of Work as a right and duty. According to this Article, work is assured as a right and duty as well as a matter of honour for all citizens. Payment for the work of every citizen according to his abilities and according to his work has been confirmed by this significant Article. In this Article the principle of work has been given significant importance, as the enjoyment of unearned incomes has been discouraged and all sorts of human labour, intellectual and physical efforts has been given much more importance.

Rural development and agricultural revolution as a principle of state policy has been discussed in Article 16 of the Constitution. Article 16 of the Constitution provides, the state is under duty to remove the inequality in respect of standard of living between rural and urban areas, the State shall take effective measures for ensuring radical improvement in the rural areas through agricultural revolution. Moreover, for the purpose of rural development: educational improvement, rural electrification, development of cottage and other industries, public health and communication in those areas should also be ensured by the State. Without development of the rural areas, the development of the country cannot imagine. As the fundamental principles are enforceable by the State, it is the responsibility of the State to take all necessary initiatives for the development of rural areas in order to upheld human rights among the people of Bangladesh. The State has taken magnificent steps and still striving for the implementation of this principle but this principle has not been completely implemented because of several obstacles.

The concept of freedom of religion or believe has been well recognised as one of the international human rights instruments. Though, recently, there is controversy regarding its status as a human right by undermining the principles of universalism, freedom, and equality; for example: combating defamation of religions, preserving a state imposed interreligious harmony, or promoting ideological versions of state secularism. However, the main idea of the freedom of religion is that, individuals are free about their beliefs on religious matters against a wide, secure background regime of freedom of speech and expression and should be 
free to join together or not to join. The principle of Secularism and freedom of religion has been considered in Article 12 of the Constitution of Bangladesh. Considering Article 12 of the Constitution, secularism can be acquired by eliminating all sort of communalism, by not granting political status in favour of any particular religion, by blocking abuse of religion for political purposes, by non-discrimination against any person practicing a particular religion. However, this Article of the Constitution ensures the removal of communalism and no particular religion shall be given political status. Moreover, abuse of religion for political purposes has been stopped and the freedom of the citizen to perform any religion has been guaranteed by this significant Article of the Constitution. This fundamental principle has not also been completely implemented as there is still religion based political parties in the State and the religion is being abused for political purposes. Politicization of religion should be stopped for the proper implementation of this principle. Thus, secularism understood about the approach of the mutual understanding among the religious groups, which comprise the nation to respect one another without any discrimination that can uphold the human rights and peace in the society.

The failure of the social and economic system to achieve a basic minimum condition of life, securing the access to basic social and economic goods and services, for millions of people in the third world became the concerning issue to the economists, philosophers and human rights advocates. However, Article 15 of the Constitution of Bangladesh deals with the provision of basic necessities. Article 15 confirms that, it is the responsibility of the Sate to attain constant increased production forces and to improve the material and cultural standard of living of the people through a planned economic growth. In this regard the State shall also secure the basic necessities of life including food, clothing, shelter, education and medical care. In respect of quantity and quality of work, the right to work that includes the right to have guaranteed employment at a reasonable wage should also be secured by the State for its citizens. Respecting workers, the State shall secure the right to reasonable rest, recreation and leisure of the workers. According to this principle, the State shall secure for its citizens the right to social security and public assistance in case of unemployment, illness or disablement, or suffered by widows or orphans or in old age or in other such cases. However, it is the fundamental responsibility of the State to ensure the basic necessities of the citizens, ensure employment for its people, and to provide social security and public assistance in case of hardship of the citizens. The State has taken remarkable steps for the implementation of this fundamental principle through enforcing different laws and regulations but could not achieve the expected goal yet, thus the goal to protect the human rights of the citizens has not been achieved.

Moreover, free and compulsory education, which is another principle of state policy, is discussed in Article 17 of the Constitution. According to Article 17 of the Constitution, it is the responsibility of the State to take necessary steps to ensure uniform, universal system of education, and ensure free and compulsory education to all children to a certain stage as determined by law. Moreover, the State shall also relate the education to the need of the society and also make initiatives to produce trained and motivated people to serve those needs. In addition to that, as per Article 17, it is the responsibility of the State to take necessary steps for removing illiteracy within a prescribed period of time. The state has taken tremendous steps for ensuring free and compulsory primary education and is very close to achieve the expected goal but the curse of illiteracy has not yet been overcome.

Furthermore, Public Health and Morality as a fundamental principle of state policy has been incorporated into Article 18 of the Constitution. As per this Article, it is a primary duty of the State to raise the level of nutrition and improve public health. Moreover, taking effective measures to prevent consumption of alcohol and other intoxicating drinks and drugs which are injurious to health, except for medical purposes and prescribed lawful purposes, is another significant duty of the State. Furthermore, in terms of morality, it is the duty of the State to adopt efficient measures to prevent prostitution and gambling. For raising nutrition level and to improve public health, the mechanisms taken by the State cannot be ignored but this principle also has not achieved the expected level yet. Moreover, the problems respecting abuse of drugs should also be removed through the proper implementation of laws. Additionally, the protection and improvement of environment and biodiversity is another fundamental principle of State policy, which is ensured in Article 18A of the Constitution. It is stated that, it is the duty of the State to take initiatives to protect and improve environment for present and future citizens of the country. It is a duty of the State to preserve and safeguard natural resources, bio-diversity, wetlands, forests and wild life. The State has passed several laws and has taken different steps for the protection of environment and the improvement of biodiversity but the State has not yet achieved the expected level.

Article 23 of the Constitution covers National culture as a fundamental principle of state policy. This Article confirms a duty upon the State to preserve cultural traditions and heritage of the citizens and to improve the national language, literature and the arts. Moreover, it is confirmed that, for the enrichment of national culture, all section of the people may have the opportunity to contribute and participate. Even the United Nations call for universal human rights in order to protect the heritage and culture of society, as individuals belongs to cultural groups. In this regards, Elazar Barkan believe that although a universal minimum of human rights exists, "many 'universal' rights have meaning mostly as they are applied within 
local variation." However, Article 23A of the Constitution deals with the culture of tribes, minor races, ethnic sects and communities. This important Article assures that it a fundamental duty of the State to take necessary measures for the protection and development of unique local culture and tradition, the tribes, minor races, ethnic sects and communities. As such the culture of tribes, minor races, ethnic sects and communities has been significantly preserved by this Article of the Constitution. Moreover, UNESC's Declaration on the International Destruction of Cultural Heritage 2003 mentioned that "cultural heritage is an important component of the cultural identity of communities, groups and individuals, and or social cohesion; so that it's intentional destruction may have adverse consequences on human dignity and human rights." Moreover, Article 24 of the Constitution deals with National monuments. This Article of the Constitution confers a duty upon the State to ensure the protection of national monument, so that none can disfigure or damage or remove such monuments. The objects or places of special artistic or historic importance have also been given protection by this Article.

Article 25 of the Constitution covers the Promotion of International peace, security and solidarity as a fundamental principle of Sate policy. This Article provides that, it is a duty of the State to show respect for national sovereignty and equality and not to interfere in the internal affairs of other countries and to settle international disputes peacefully and to show respect for international law and principles enunciated in the United Nations Charter, where the main aim is to establish rule of law and uphold human rights. In this regard, the State shall not use force in international relations and shall strive for general and complete disarmament. Moreover, the right of every people to freely determine and build up its own social, economic and political system by ways and means of its own free choice has been preserved by this Article. In addition to that, a just struggle against imperialism, colonialism or racialism may also be supported by the State. Duties of citizens and of public servants, as a fundamental principle of state policy, have been considered in Article 21 of the Constitution of the Peoples' Republic of Bangladesh. Several duties are conferred to the citizens and public servants by this Article, which also linked with the human rights of the citizens. According to this Article, every citizen of the State also has a duty to show respect towards the Constitution and other laws of the State and to maintain discipline and to perform public duties as well as to protect public property. Moreover, this Article confirms that it is the duty of every person in the service of the Republic to give full effort to serve the people all time.

However, the separation of judiciary from the executive, a fundamental principle of State policy, is ensured in Article 22 of the Constitution. In this Article it is assured that, it is a fundamental duty of the State to ensure separation of judiciary from the executive organs of the State in order to uphold rule of law and human rights. The historical Masder Hossain case, which is also known as "judicial independence" or the "separation of judiciary" case has given significant guidelines to the government for ensuring separation of judiciary from the executive. As the Supreme Court is the guardian of the Constitution and the fundamental principles are not enforceable by the judiciary, the Appellate Division provided directions to the State for its enforceability.

\section{ROLE OF JUDICIARY IN PROTECTING HUMAN RIGHTS}

Judicial hands are open in protecting fundamental rights those are ensured under Part III of the Constitution of the People's Republic of Bangladesh. Article 44 of the Constitution ensures that, for the implementation of those fundamental rights people may go before the High Court Division of the Supreme Court of Bangladesh with a Writ petition under Article 102 of the Constitution. However, this rule is not applicable for the principles laid down in Part II of the Constitution. Judicial hands are tied in respect of implementing those Fundamental Principles of State Policy. People are not allowed to go before any court for the implementation of the Fundamental Principles of State Policies mentioned in Part II of the Constitution. Article 8(2) of the Constitution ensures that, principles in Part II of the Constitution are fundamental to the government and they are not judicially enforceable. However, the government should bear in mind that, those principles are the political commitments of the government to the people at large and should not be kept unimplemented for a long period of time. Moreover, if the hands of the judiciary remain tied in respect of implementing those principles; the government might show unwillingness to implement those principles and the people at large will face miscarriage of justice.

\section{CONCLUSION}

In conclusion it can be said that, it is about 45 years we have achieved our independence and got a sovereign country. But only a few of the fundamental principle of state policy have been assured completely till today, thought under the fundamental rights the limit seems more extensive. Vast works are yet to be done for the complete implementation of the fundamental principles of state policy, though the State is taking significant steps in respect of implementing the fundamental principles of state policy. Some of the fundamental principles of the state policy have not achieved that envious goal in order to get the targeted human rights protection; and 
the State should ensure complete implementation of those principles. In respect of implementing the fundamental principles of state policy, the socio-economic perspective of the Republic should also take into account. The fundamental principles of the state policy can never be implemented with a miracle. None knows when the government will achieve the goal of complete implementation of the fundamental principles as there are still some unavoidable problems in the State. However, if the judiciary's hands remains tied in protecting human rights, government might not be willing to ensure the fundamental rights which might go against their own interests.

\section{REFERENCES}

[1] Halim, M. A. (2014). The Legal System of Bangladesh (8th ed.). Dhaka: CCB Foundation.

[2] Islam, M. (2002). Constitutional Law of Bangladesh (2nd ed.). Dhaka: Mullick Brothers.

[3] Kamal, M. J. (1994). Bangladesh Constitution: Trends and Issues (1st ed.). Dhaka, Bangladesh: Dhaka University.

[4] Arneson, R.J. (2016). Freedom and Religion. In The Oxford Handbook of Freedom.

[5] Bielefeldt, H. (2013). Misperceptions of Freedom of Religion or Belief. Human Rights Quarterly, 35(1), pp.33-68.

[6] Buchanan, A. (2005). Equality and human rights. Politics, philosophy \& economics, SAGE Publications Ltd. London, 4(1), pp.69-90.

[7] Cole, M. (2011). Education, equality and human rights: issues of gender,'race', sexuality, disability and social class. Routledge. P 1-6.

[8] Halim, M. A, (2008). Constitution, constitutional law and politics: Bangladesh perspective, Dhaka: CCB Foundation.

[9] Stewart, F. (1989). Basic needs strategies, human rights, and the right to development. Human Rights Quarterly, 11(3), pp.347-374 and human rights (pp. 3-29). Springer New York.

[10] The Constitution of the People's Republic of Bangladesh. 